\title{
ANALISIS PENERAPAN BATAS USIA PESAWAT CESSNA 402B UNTUK TRANSPORT CATEGORY
}

\author{
Raden Yunus Ardianto, Freddy Franciscus, Wahyuni Tri Utami ${ }^{\star}$ \\ Prodi Teknik Penerbangan Fakultas Teknologi Kedirgantaraan, \\ Universitas Dirgantara Marsekal Suryadarma \\ ${ }^{*}$ Corresponding Author : wahyuni3utami@gmail.com
}

\begin{abstract}
Abstrak - Banyak penyebab terjadinya kecelakaan pesawat salah satunya adalah kegagalan pesawat dalam beroperasi dengan normal yang dikarenakan usia pesawat yang sudah tua. Penetapan peraturan pembatasan usia pesawat terbang diberlakukan untuk menekan jumlah kecelakaan pesawat terbang. Pesawat yang dimiliki Whitesky Aviation yaitu pesawat Cessna 402B adalah pesawat yang dipergunakan untuk misi kegiatan foto udara. Pembatasan usia pesawat yang dilarang untuk beroperasi adalah 45 tahun. Perhitungan jam terbang pesawat Cessna 402B menurut rekaman data saat ini jika dilakukan perkiraan disaat mencapai usia 45 , kondisi pesawat masih dalam kondisi yang baik. Sehingga peraturan pembatasan usia menjadi hal yang kurang sesuai untuk diterapkan jika diberlakukan pada pesawat yang hanya memiliki jam terbang yang rendah. Pada penulisan tugas akhir ini bertujuan untuk menentukan pengaruh usia Cessna 420B terhadap operasional dan maintenance serta batas usia yang sesuai dengan perbandingan shedule maintenance menurut Flight Hours dan Flight Cycle. Dan pada Operasi low utilization tidak terdapat perbedaan pengoperasian pesawat berdasarkan umur pesawat, utilisasi pesawat tidak mempengaruhi jumlah maintenance menurut calender time serta batasan umur pesawat tersebut belum tercapai sehingga masih memiliki banyak sisa umur. Pesawat PK-WLW memiliki sisa umur 29882.4FH dan pesawat PK-WLY memiliki sisa umur 31405.2FH.
\end{abstract}

Kata Kunci : Usia Pesawat, Cessna 402B, Transport Category, PK-WLW, PK-WLY

\begin{abstract}
Many causes of aircraft accidents one of which is the failure of the aircraft to operate normally due to the age of the aircraft that is old. Stipulation of aircraft age restriction regulations are applied to reduce the number of aircraft accidents. The aircraft owned by Whitesky Aviation, the Cessna 402B is an aircraft used for aerial photography activities. Age restrictions on aircraft that are prohibited from operating are 45 years. Calculation of flight hours of the Cessna $402 B$ according to current data records if an estimate is made when reaching the age of 45, the condition of the aircraft is still in good condition. So that age-limiting regulations are not appropriate to apply if applied to aircraft that only have low flight hours. At the writing of this final project aims to determine the influence of the age of the Cessna 420B on operational and maintenance and age limits in accordance with the comparison of maintenance shedule according to Flight Hours and Flight Cycle. And in low utilization operations there is no difference in aircraft operations based on aircraft age, aircraft utilization does not affect the number of maintenance according to the calender time and the age limit of the aircraft has not been reached so that it still has a lot of remaining life. PK-WLW aircraft have a remaining life of 29882.4FH and PK-WLY aircraft have a remaining life of 31405.2FH.
\end{abstract}

Keywords : Aircraft Age, Cessna 402B,Transport Category PK-WLW, PK-WLY

\section{PENDAHULUAN}

Salah satu kemungkinan alasan pembatasan usia operasi pesawat adalah untuk meningkatkan aspek keselamatan dan menekan salah satu penyebab banyak terjadinya kecelakaan pesawat. Kecelakaan pesawat bisa disebabkan oleh kondisi pesawat terbang yang sudah mulai memasuki usia tua. Pembatasan usia pesawat dilakukan olek Kementerian Perhubungan untuk pesawat jenis angkutan udara niaga. Namun bagaimana dampak penerapan tersebut jika diterapkan pada pesawat dengan jenis penggunaan lain. 
Misalnya saat ini Whitesky Aviation mengoperasikan pesawat dengan jenis utility yang dimanfaatkan untuk kegiatan foto udara. Berbeda dengan pesawat angkutan niaga dan cargo yang dimana frekuensi penggunaan operasional pesawat Whitesky Aviation tidak sesering pesawat angkutan udara niaga dan kargo.

Kemampuan operasional pesawat bisa ditinjau tidak hanya didasari oleh usia pesawat saja (calender time) namun perlu diperhatikan juga aspek usia dari pemakaian pesawat (flight hour dan flight cycle).

\section{METODE PENELITIAN}

Cessna meliputi operasi pada pengunaan pesawat yang rendah (low utilization) dan batas operasi menurut calendar time. Operasi pesawat Cessna 402B juga berhubungan dengan jadwal maintenance yang berdasarkan menurut calender time atau menurut Flight Hour. Dari operasi dan maintenance akan dibandingkan dan dianalisis untuk dilihat sisa umur pesawat Cesna 402B.

\subsection{Spesifikasi Pesawat Cessna 402B}

$\begin{array}{ll}\text { A. General characteristics } \\ \text { Crew } & : \text { Two pilots } \\ \text { Capacity } & : \text { Six passengers } \\ \text { Length } & : 36 \mathrm{ft} 4 \frac{1}{2} \text { in }(11.087 \mathrm{~m}) \\ \text { Wingspan } & : 44 \mathrm{ft} 1 \frac{1}{2} \text { in }(13.449 \mathrm{~m}) \\ \text { Height } & : 11 \mathrm{ft} 51 / 2 \text { in }(3.493 \mathrm{~m}) \\ \text { Wing area } & : 225,8 \mathrm{sq} \mathrm{ft}\left(20,98 \mathrm{~m}^{2)}\right. \\ \text { Airfoil } & : \text { NACA } 23018 \text { (root) } \\ & \text { NACA } 23015 \text { (tip) }\end{array}$

Empty weight $: 4.077 \mathrm{lb}(1.849 \mathrm{~kg})$

Max takeoff weight : $6.850 \mathrm{lb}(3.107 \mathrm{~kg})$

Fuel capacity : 206 US gal

(172 imp gal; 780 L)

usable fuel Powerplant :

$2 \times$ Continental TSIO-520-VB

air-cooled turbocharged

flat-six engines

$325 \mathrm{hp} \mathrm{(242} \mathrm{kW)} \mathrm{each}$

\section{Propellers : 3-bladed \\ McCauley 0850334-34 \\ constant speed propeller}

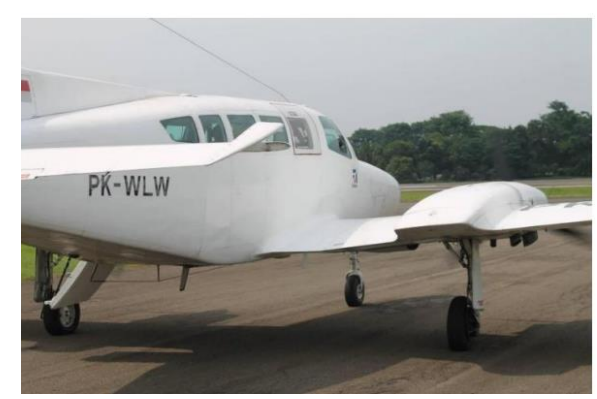

Gambar 1. Pesawat Cessna 402B[6]

\section{B. Performance}

Maximum speed : $231 \mathrm{kn}$

(266 mph; $428 \mathrm{~km} / \mathrm{h}$ ) at $16.000 \mathrm{ft} \mathrm{(4.900}$ $\mathrm{m})$

Cruise speed : $142 \mathrm{kn}$

(163 mph; $263 \mathrm{~km} / \mathrm{h})$ at $10.000 \mathrm{ft}(3.000$ $\mathrm{m})$, econ cruise

Stall speed $\quad: 68 \mathrm{kn}$

(78 mph; $126 \mathrm{~km} / \mathrm{h}$ )

(flaps down, power off) (CAS)

Never exceed speed : $231 \mathrm{kn}$

(266 mph; $428 \mathrm{~km} / \mathrm{h}$ )

Range : $1.273 \mathrm{nmi}$

$(1.465 \mathrm{mi} ; 2.358 \mathrm{~km})$ at $10.000 \mathrm{ft}(3.000$ $\mathrm{m})$, econ cruise

Service ceiling $\quad: 26.900 \mathrm{ft}(8.200 \mathrm{~m})$

Rate of climb $: 1.450 \mathrm{ft} / \mathrm{min}$ $(7,4 \mathrm{~m} / \mathrm{s})$

Takeoff distance to $50 \mathrm{ft}(15 \mathrm{~m})$ $: 2.195 \mathrm{ft}(669 \mathrm{~m})$

Landing distance from $50 \mathrm{ft}(15 \mathrm{~m})$ $: 2.485 \mathrm{ft}(757 \mathrm{~m})$

\section{HASIL DAN PEMBAHASAN}

\subsection{Data Utilisasi}

Berdasarkan Tabel 1 diketahui Flight hours dan Flight cycle bulanan sehingga dapat dihitung $\mathrm{FH}$ dan $\mathrm{FC}$ dalam satu tahun. Berdasarkan utilisasi dalam satu tahun, maka dapat ditentukan berapa kali maintenance harus dilakukan dalam satu tahun. 
Tabel 1. Data Utilisasi ${ }^{[10]}$

\begin{tabular}{|c|c|c|c|c|c|c|}
\hline $\begin{array}{l}\text { Perio } \\
\text { de }\end{array}$ & $\begin{array}{c}\text { Type } \\
\text { Aircraft }\end{array}$ & $\begin{array}{l}\mathbf{S} \\
/ \\
\mathbf{N}\end{array}$ & $\begin{array}{c}\text { Registra } \\
\text { si }\end{array}$ & $\begin{array}{l}\text { Flight } \\
\text { Hours }\end{array}$ & $\begin{array}{l}\text { Flight } \\
\text { Cycle }\end{array}$ & $\begin{array}{l}\text { B } \\
\text { a } \\
\text { s } \\
\text { e }\end{array}$ \\
\hline \multirow[t]{2}{*}{ JAN } & $\begin{array}{c}\text { CESSNA } \\
402 \mathrm{~B}\end{array}$ & $\begin{array}{l}5 \\
5 \\
5\end{array}$ & $\begin{array}{l}\text { PK- } \\
\text { WLW }\end{array}$ & 10000.1 & 15927 & $\begin{array}{l}\mathrm{H} \\
\mathrm{L} \\
\mathrm{P}\end{array}$ \\
\hline & $\begin{array}{c}\text { CESSNA } \\
402 \mathrm{~B}\end{array}$ & $\begin{array}{l}5 \\
4 \\
1\end{array}$ & PK-WLY & 8302.7 & 13701 & $\begin{array}{l}\mathrm{H} \\
\mathrm{L} \\
\mathrm{P}\end{array}$ \\
\hline \multirow[t]{2}{*}{ FEB } & $\begin{array}{c}\text { CESSNA } \\
402 \mathrm{~B}\end{array}$ & $\begin{array}{l}5 \\
5 \\
5\end{array}$ & $\begin{array}{l}\text { PK- } \\
\text { WLW }\end{array}$ & 10000.1 & 15927 & $\begin{array}{l}\mathrm{H} \\
\mathrm{L} \\
\mathrm{P}\end{array}$ \\
\hline & $\begin{array}{c}\text { CESSNA } \\
402 \mathrm{~B}\end{array}$ & $\begin{array}{l}5 \\
4 \\
1\end{array}$ & PK-WLY & 8302.7 & 13701 & $\begin{array}{l}\mathrm{H} \\
\mathrm{L} \\
\mathrm{P}\end{array}$ \\
\hline \multirow[t]{2}{*}{ MAR } & $\begin{array}{c}\text { CESSNA } \\
402 \mathrm{~B}\end{array}$ & $\begin{array}{l}5 \\
5 \\
5\end{array}$ & $\begin{array}{l}\text { PK- } \\
\text { WLW }\end{array}$ & 10000.1 & 15927 & $\begin{array}{l}\mathrm{H} \\
\mathrm{L} \\
\mathrm{P}\end{array}$ \\
\hline & $\begin{array}{c}\text { CESSNA } \\
402 \mathrm{~B}\end{array}$ & $\begin{array}{l}5 \\
4 \\
1\end{array}$ & PK-WLY & 8302.7 & 13701 & $\begin{array}{l}\mathrm{H} \\
\mathrm{L} \\
\mathrm{P}\end{array}$ \\
\hline \multirow[t]{2}{*}{ APR } & $\begin{array}{c}\text { CESSNA } \\
402 \mathrm{~B}\end{array}$ & $\begin{array}{l}5 \\
5 \\
5\end{array}$ & $\begin{array}{l}\text { PK- } \\
\text { WLW }\end{array}$ & 10005.8 & 15929 & $\begin{array}{l}\mathrm{M} \\
\mathrm{L} \\
\mathrm{N}\end{array}$ \\
\hline & $\begin{array}{c}\text { CESSNA } \\
402 \mathrm{~B}\end{array}$ & $\begin{array}{l}5 \\
4 \\
1\end{array}$ & PK-WLY & 8309.9 & 13706 & $\begin{array}{l}\mathrm{M} \\
\mathrm{L} \\
\mathrm{N}\end{array}$ \\
\hline \multirow[t]{2}{*}{ MEI } & $\begin{array}{c}\text { CESSNA } \\
402 \mathrm{~B}\end{array}$ & $\begin{array}{l}5 \\
5 \\
5\end{array}$ & $\begin{array}{l}\text { PK- } \\
\text { WLW }\end{array}$ & - & - & $\begin{array}{l}\mathrm{M} \\
\mathrm{L} \\
\mathrm{N}\end{array}$ \\
\hline & $\begin{array}{c}\text { CESSNA } \\
402 \mathrm{~B}\end{array}$ & $\begin{array}{l}5 \\
4 \\
1\end{array}$ & PK-WLY & - & - & $\begin{array}{l}\mathrm{M} \\
\mathrm{L} \\
\mathrm{N}\end{array}$ \\
\hline \multirow[t]{2}{*}{ JUN } & $\begin{array}{c}\text { CESSNA } \\
402 \mathrm{~B}\end{array}$ & $\begin{array}{l}5 \\
5 \\
5\end{array}$ & $\begin{array}{l}\text { PK- } \\
\text { WLW }\end{array}$ & 10086 & 15959 & $\begin{array}{l}\mathrm{H} \\
\mathrm{L} \\
\mathrm{P}\end{array}$ \\
\hline & $\begin{array}{c}\text { CESSNA } \\
402 \mathrm{~B}\end{array}$ & $\begin{array}{l}5 \\
4 \\
1\end{array}$ & PK-WLY & 8360.3 & 13726 & $\begin{array}{l}\mathrm{H} \\
\mathrm{L} \\
\mathrm{P}\end{array}$ \\
\hline \multirow[t]{2}{*}{ JUL } & $\begin{array}{c}\text { CESSNA } \\
402 \mathrm{~B}\end{array}$ & $\begin{array}{l}5 \\
5 \\
5\end{array}$ & $\begin{array}{l}\text { PK- } \\
\text { WLW }\end{array}$ & 10117.6 & 15972 & $\begin{array}{l}\mathrm{H} \\
\mathrm{L} \\
\mathrm{P}\end{array}$ \\
\hline & $\begin{array}{c}\text { CESSNA } \\
402 \mathrm{~B}\end{array}$ & $\begin{array}{l}5 \\
4 \\
1\end{array}$ & PK-WLY & 8364.8 & 13730 & $\begin{array}{l}\mathrm{H} \\
\mathrm{L} \\
\mathrm{P}\end{array}$ \\
\hline \multirow[t]{2}{*}{ AUG } & $\begin{array}{c}\text { CESSNA } \\
402 \mathrm{~B}\end{array}$ & $\begin{array}{l}5 \\
5 \\
5\end{array}$ & $\begin{array}{l}\text { PK- } \\
\text { WLW }\end{array}$ & 10117 & 15972 & $\begin{array}{l}\mathrm{H} \\
\mathrm{L} \\
\mathrm{P}\end{array}$ \\
\hline & $\begin{array}{c}\text { CESSNA } \\
402 \mathrm{~B}\end{array}$ & $\begin{array}{l}5 \\
4 \\
1 \\
\end{array}$ & PK-WLY & 8406.7 & 13754 & $\begin{array}{l}\mathrm{T} \\
\mathrm{N} \\
\mathrm{J}\end{array}$ \\
\hline \multirow[t]{2}{*}{ SEP } & $\begin{array}{c}\text { CESSNA } \\
402 \mathrm{~B}\end{array}$ & $\begin{array}{l}5 \\
5 \\
5\end{array}$ & $\begin{array}{l}\text { PK- } \\
\text { WLW }\end{array}$ & 10117.6 & 15972 & $\begin{array}{l}\mathrm{H} \\
\mathrm{L} \\
\mathrm{P}\end{array}$ \\
\hline & $\begin{array}{c}\text { CESSNA } \\
402 \mathrm{~B}\end{array}$ & $\begin{array}{l}5 \\
4 \\
1\end{array}$ & PK-WLY & 8455.2 & 13778 & $\begin{array}{l}\mathrm{T} \\
\mathrm{N} \\
\mathrm{J}\end{array}$ \\
\hline \multirow[t]{2}{*}{ OCT } & $\begin{array}{c}\text { CESSNA } \\
402 \mathrm{~B}\end{array}$ & $\begin{array}{l}5 \\
5 \\
5\end{array}$ & $\begin{array}{l}\text { PK- } \\
\text { WLW }\end{array}$ & - & - & $\begin{array}{l}\mathrm{H} \\
\mathrm{L} \\
\mathrm{P}\end{array}$ \\
\hline & $\begin{array}{c}\text { CESSNA } \\
402 \mathrm{~B}\end{array}$ & $\begin{array}{l}5 \\
4 \\
1\end{array}$ & PK-WLY & - & - & $\begin{array}{l}\mathrm{T} \\
\mathrm{N} \\
\mathrm{J}\end{array}$ \\
\hline
\end{tabular}

Berdasarkan tabel tersebut diketahui Flight hours dan Flight cycle bulanan sehingga dapat dihitung $\mathrm{FH}$ dan $\mathrm{FC}$ dalam satu tahun. Berdasarkan utilisasi dalam satu tahun, maka dapat ditentukan berapa kali maintenance harus dilakukan dalam satu tahun. Jumlah maintenance yang harus dilakukan untuk kedua pesawat terdapat pada Tabel 2 dan Tabel 3.

Berdasarkan data utilisasi bulanan di atas maka dapat dihitung jumlah maintenance yang harus dilakukan untuk setiap jenis maintenance. Sebagai contoh maintenance setiap $50 \mathrm{FH}$, untuk total $\mathrm{FH}$ pesawat PK-WLW sebanyak 125,7 FH maka diperlukan 3 kali maintenance $50 \mathrm{FH}$. Jika seluruh maintenance yang harus dilakukan dalam setahun dihitung maka akan dihasilkan seperti tabel di bawah ini Berdasarkan data utilisasi bulanan di atas maka dapat dihitung jumlah maintenance yang harus dilakukan untuk setiap jenis maintenance. Sebagai contoh maintenance setiap $50 \mathrm{FH}$, untuk total $\mathrm{FH}$ pesawat PK-WLW sebanyak 125,7 FH maka diperlukan 3 kali maintenance $50 \mathrm{FH}$. Jika seluruh maintenance yang harus dilakukan dalam setahun dihitung maka akan dihasilkan seperti Tabel 4.

Selain maintenance berdasarkan Flight Hour dan Flight Cycle, juga diperlukan maintenance prolong karena pesawat tidak selalu terbangdalamtiap minggu. Jumlah prolong seperti pada Tabel 5 dan Tabel 6 .

Tabel 2. Flight Hour

\begin{tabular}{|c|c|c|c|c|c|c|c|c|c|c|c|c|c|}
\hline $\begin{array}{c}\text { Type } \\
\text { Aircraf }\end{array}$ & JAN & FEB & MAR & APR & MEI & JUN & JUL & AUG & SEP & OCT & NOP & DES & TOTAL \\
\hline $\begin{array}{c}\text { PK- } \\
\text { WLW }\end{array}$ & 0 & 0 & 0 & 5.7 & 0 & 80 & 31 & 0 & 0 & 0 & 0 & 0 & 116.7 \\
\hline $\begin{array}{l}\text { PK- } \\
\text { WLY }\end{array}$ & 0 & 0 & 0 & 7.2 & 0 & 50 & 4.5 & 41 & 48 & 0 & 78 & 60 & 289.7 \\
\hline
\end{tabular}


Tabel 3. Flight Cycle

\begin{tabular}{|c|c|c|c|c|c|c|c|c|c|c|c|c|c|}
\hline $\begin{array}{l}\text { Type } \\
\text { Aircraft }\end{array}$ & JAN & FEB & MAR & APR & MEI & JUN & JUL & AUG & SEP & OCT & NOP & DES & TOTAL \\
\hline $\begin{array}{l}\text { PK- } \\
\text { WLW }\end{array}$ & 0 & 0 & 0 & 3 & 0 & 30 & 13 & 0 & 0 & 0 & 0 & 0 & 46 \\
\hline $\begin{array}{l}\text { PK- } \\
\text { WLY }\end{array}$ & 0 & 0 & 0 & 5 & 0 & 20 & 27 & 24 & 24 & 0 & 37 & 20 & 157 \\
\hline
\end{tabular}

Tabel 4. Total Maintenance

\begin{tabular}{|c|c|c|c|}
\hline Item & $\begin{array}{c}\text { Flight } \\
\text { Hours }\end{array}$ & $\begin{array}{c}\text { PK- } \\
\text { WLW }\end{array}$ & $\begin{array}{c}\text { PK- } \\
\text { WLY }\end{array}$ \\
\hline $\begin{array}{c}\text { Special } \\
\text { Inspection }\end{array}$ & $50 H / 12 M$ & 2 & 5 \\
\hline $\begin{array}{c}\text { Special } \\
\text { Inspection }\end{array}$ & $100 H / 12 M$ & 1 & 2 \\
\hline $\begin{array}{c}\text { Special } \\
\text { Inspection }\end{array}$ & $200 H / 12 M$ & 1 & 1 \\
\hline $\begin{array}{c}\text { Corrosion } \\
\text { Program } \\
\text { Inspection }\end{array}$ & $12 M$ & 1 & 1 \\
\hline $\begin{array}{c}\text { Servicing } \\
\text { Servicing }\end{array}$ & $100 \mathrm{H} / 12 \mathrm{M}$ & 1 & 2 \\
\hline $\begin{array}{c}\text { Supplemental } \\
\text { Inspection } \\
\text { Directive }\end{array}$ & $500 \mathrm{LL} / 1 \mathrm{Y}$ & 1 & 1 \\
\hline $\begin{array}{c}\text { Instruction } \\
\text { Continued } \\
\text { Airworthiness }\end{array}$ & $100 \mathrm{H} / 12 \mathrm{M}$ & 1 & 2 \\
\hline \multicolumn{1}{|c|}{ TOTAL } & 10 & 19 \\
\hline
\end{tabular}

\subsection{Data Simulasi}

Berdasarkan Service Manual dari Cessna 402B diperoleh data flight length summary dari berbagai operator pesawat cessna 402 seperti pada Gambar 1. Dikarenakan jam terbang pesawat ini tidak tentu, jadi diambil grafik flight length summary yang lebih banyak terbang dengan jarak 3 kali perminggu dengan lama penerbangan 1,6 jam. Maka digunakan salah satu flight length summary sebagai perbandingan dan dipilih pesawat dengan frekuensi penerbangan 3 kali perminggu dengan lama penerbangan 1,6 jam setiap cyclenya. Maka FH dan FC pesawat tersebut seperti pada Tabel 7 dan Tabel 8.

Dari pesawat tersebut maka dapat diperkirakan jumlah maintenance yang harus dilakukan seperti pada Tabel 9.

Tabel 5. Prolong Weekly

\begin{tabular}{|c|c|c|c|c|c|c|c|c|c|c|c|c|c|}
\hline $\begin{array}{c}\text { Type } \\
\text { Aircraft }\end{array}$ & JAN & FEB & MAR & APR & MEI & JUN & JUL & AUG & SEP & OCT & NOP & DES & TOTAL \\
\hline PK-WLW & 4 & 4 & 4 & 2 & 4 & 0 & 0 & 0 & 4 & 4 & 4 & 4 & 38 \\
\hline PK-WLY & 4 & 4 & 4 & 1 & 4 & 0 & 3 & 0 & 0 & 4 & 0 & 0 & 24 \\
\hline
\end{tabular}

Tabel 6. Prolong Mounthly

\begin{tabular}{|c|c|c|c|c|c|c|c|c|c|c|c|c|c|}
\hline $\begin{array}{c}\text { Type } \\
\text { Aircraft }\end{array}$ & JAN & FEB & MAR & APR & MEI & JUN & JUL & AUG & SEP & OCT & NOP & DES & TOTAL \\
\hline PK-WLW & 1 & 1 & 1 & 0 & 1 & 0 & 0 & 1 & 1 & 1 & 1 & 1 & 9 \\
\hline PK-WLY & 1 & 1 & 1 & 0 & 1 & 0 & 0 & 0 & 0 & 1 & 0 & 0 & 5 \\
\hline
\end{tabular}


Tabel 7. Flight Hours

\begin{tabular}{|c|c|c|c|c|c|c|c|c|c|c|c|c|c|}
\hline $\begin{array}{c}\text { Type } \\
\text { Aircraft }\end{array}$ & JAN & FEB & MAR & APR & MEI & JUN & JUL & AUG & SEP & OCT & NOP & DES & TOTAL \\
\hline PK-WLW & 19.2 & 19.2 & 19.2 & 19.2 & 19.2 & 19.2 & 19.2 & 19.2 & 19.2 & 19.2 & 19.2 & 19.2 & 230.4 \\
\hline PK-WLY & 19.2 & 19.2 & 19.2 & 19.2 & 19.2 & 19.2 & 19.2 & 19.2 & 19.2 & 19.2 & 19.2 & 19.2 & 230.4 \\
\hline
\end{tabular}

Tabel 8. Flight Cycle

\begin{tabular}{|c|c|c|c|c|c|c|c|c|c|c|c|c|c|}
\hline $\begin{array}{c}\text { Type } \\
\text { Aircraft }\end{array}$ & JAN & FEB & MAR & APR & MEI & JUN & JUL & AUG & SEP & OCT & NOP & DES & TOTAL \\
\hline PK-WLW & 12 & 12 & 12 & 12 & 12 & 12 & 12 & 12 & 12 & 12 & 12 & 12 & 144 \\
\hline PK-WLY & 12 & 12 & 12 & 12 & 12 & 12 & 12 & 12 & 12 & 12 & 12 & 12 & 144 \\
\hline
\end{tabular}

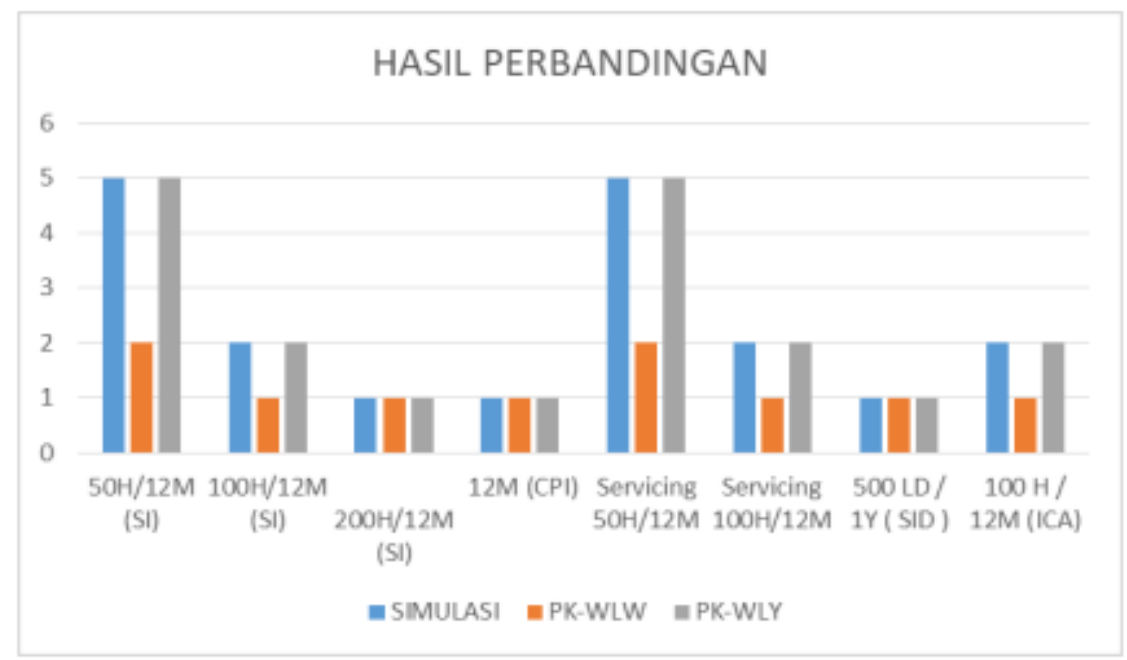

Gambar 2. Hasil perbandingan

Tabel 9. Total Maintenance

\begin{tabular}{|c|c|c|}
\hline Item & $\begin{array}{l}\text { Flight } \\
\text { Hours }\end{array}$ & Simulasi \\
\hline Special Inspection & $50 H / 12 M$ & 5 \\
\hline Special Inspection & $100 \mathrm{H} / 12 \mathrm{M}$ & 2 \\
\hline Special Inspection & $200 H / 12 M$ & 1 \\
\hline $\begin{array}{l}\text { Corrosion Program } \\
\text { Inspection }\end{array}$ & $12 M$ & 1 \\
\hline Servicing & $50 H / 12 M$ & 5 \\
\hline Servicing & $100 \mathrm{H} / 12 \mathrm{M}$ & 2 \\
\hline $\begin{array}{c}\text { Supplemental Inspection } \\
\text { Directive }\end{array}$ & $500 L D / 1 Y$ & 1 \\
\hline $\begin{array}{l}\text { Instruction Continued } \\
\text { Airworthiness }\end{array}$ & $100 H / 12 M$ & 2 \\
\hline Total & & 19 \\
\hline
\end{tabular}

\subsection{Analisis Frekuensi Maintenance}

Jika maintenance yang harus dilakukan antara ketiga pesawat dibandingkan maka diperoleh hasil seperti pada Gambar 2.. Pada Tabel 4 dapat disimpulkan bahwa kedua pesawat telah melaksanakan special inspection, servicing, Corrosion Program Inspection (CPI), Supplemental Inspection Directive (SID) dan Instruction Continued Airworthinees (ICA). Berdasarkan data tersebut yang dilakukan terhadap kedua pesawat dengan flight hours yang terdapat di Maintenance Program. Perawatan juga dilakukan ketika pesawat tidak dalam kondisi beroperasi yakni dengan prolong pada tiap minggu.Pada Gambar 2.1 dari data simulasi pesawat Cessna 402B telah melaksanakan special inspection, servicing, Corrosion Program Inspection (CPI), Supplemental Inspection Directive 
(SID) dan Instruction Continued Airworthinees (ICA).

Berdasarkan data tersebut terdapat pada service manual.Berdasarkan hasil grafik perbandingan Gambar 4.2 di bawah ini menjelaskan pesawat yang registrasi PKWLW dan PK-WLY melakukan maintenance yang sama. Perbandingan grafik pada pesawat simulasi memerlukan jumlah maintenance yang lebih banyak daripada pesawat PK-WLW dan PK-WLY, terutama pada maintenance $50 \mathrm{FH}$ Special Inspection dan 50 FH Servicing. Pada maintenance 200 $\mathrm{FH}, \mathrm{CPI}$, dan 500 LD jumlah maintenance yang harus dilakukan sama antara PK-WLW, PK-WLY dan Simulasi. Berdasarkan hal tersebut, maka utilisasi pesawat tidak mempengaruhi jumlah maintenance menurut calender time. Dengan demikian jika pesawat dengan utilisasi rendah dan usia tua maka jumlah maintenance berdasarkan calender time yang harus dilakukan menjadi tidak efisien.Dengan demikian meskipun utilisasi PK-WLW dan PK-WLY sekitar setengah dari utilisasi pesawat simulasi, tapi banyak maintenance yang sama dan hanya sedikit yang berbeda. Selain itu PK-WLW dan PK-WLY tetap membutuhkan maintenance prolong setiap minggunya walaupun tidak beroperasi. Hal ini juga harus di Perhitungkan dari segi biaya yang keluar karena dari maintenance tersebut, sehingga utilisasi pesawat PK-WLW dan PK-WLY dapat dikatakan tidak efisien dari sisi maintenance.

Beberapa item maintenance menggunakan jumlah landing atau flight cycle sebagai interval maintenance, terutama pada supplemental inspection directives $(S I D)$. Supplemental Inspection
Directives memiliki Item maintenance dan hanya satu yang memiliki interval 1 tahun, yaitu pemeriksaan pada MLG Torque Tube Assy. Pemeriksaan pada komponen ini selain dengan interval 1 tahun juga menggunakan interval 500 FC. Berdasarkan data utilisasi PK-WLW dan PK-WLY maka item ini akan dikerjakan berdasarkan batasan interval calendar daripada FC karena FC per tahun sekitar 134 FC jauh dari batasan $500 \mathrm{FC}$.

Item pemeriksaan lainnya memiliki interval terdekat 3 tahun atau 500 FC yaitu pemeriksaan pada MLG Bell crank pivot bolt. Jika digunakan utilisasi yang sama, maka batasan interval lebih cepat tercapai menurut calendar daripada FC. Item pemeriksaan lain memiliki batasan interval yang lebih besar sehingga lebih lama tercapai baik menurut calendar maupun FC.

\subsection{Utilisasi Maximum}

Berdasarkan data utilisasi pesawat PK-WLW dan PK-WLY salah satu bulan memiliki utilisasi $80 \mathrm{FH}$ yang merupakan utilisasi terbesar selama pesawat tersebut dioperasikan dalam satu tahun. Jika dilakukan perbandingan simulasi pesawat dengan utilisasi maksimum tersebut setiap bulan maka berdasarkan service manual dari Cessna 402B diperoleh flight length dan frekuensi yang paling mendekati. Jika digunakan salah satu flight length summary sebagai perbandingan dan dipilih pesawat dengan frekuensi penerbangan 15 kali perminggu dengan lama penerbangan 1,4 jam setiap cyclenya, maka $\mathrm{FH}$ dan $\mathrm{FC}$ pesawat tersebut seperti pada Tabel 10 dan Tabel 11.

Tabel 10. Flight Hours

\begin{tabular}{|c|c|c|c|c|c|c|c|c|c|c|c|c|c|}
\hline $\begin{array}{c}\text { Type } \\
\text { Aircraft }\end{array}$ & JAN & FEB & MAR & APR & MEI & JUN & JUL & AUG & SEP & OCT & NOP & DES & TOTAL \\
\hline $\begin{array}{c}\text { PK- } \\
\text { WLW }\end{array}$ & 84 & 84 & 84 & 84 & 84 & 84 & 84 & 84 & 84 & 84 & 84 & 84 & 1008 \\
\hline $\begin{array}{c}\text { PK- } \\
\text { WLY }\end{array}$ & 84 & 84 & 84 & 84 & 84 & 84 & 84 & 84 & 84 & 84 & 84 & 84 & 1008 \\
\hline
\end{tabular}

Tabel 11. Flight Cycle

\begin{tabular}{|c|c|c|c|c|c|c|c|c|c|c|c|c|c|}
\hline $\begin{array}{c}\text { Type } \\
\text { Aircraft }\end{array}$ & JAN & FEB & MAR & APR & MEI & JUN & JUL & AUG & SEP & OCT & NOP & DES & TOTAL \\
\hline $\begin{array}{c}\text { PK- } \\
\text { WLW }\end{array}$ & 60 & 60 & 60 & 60 & 60 & 60 & 60 & 60 & 60 & 60 & 60 & 60 & 720 \\
\hline $\begin{array}{c}\text { PK- } \\
\text { WLY }\end{array}$ & 60 & 60 & 60 & 60 & 60 & 60 & 60 & 60 & 60 & 60 & 60 & 60 & 720 \\
\hline
\end{tabular}




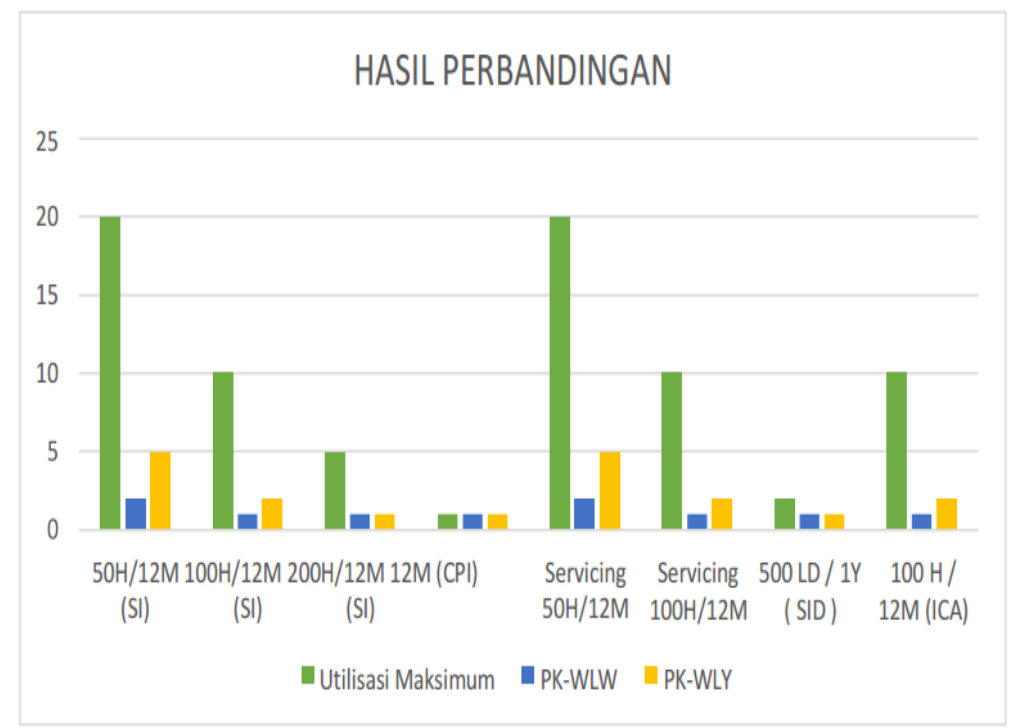

Gambar 3.Hasil Perbandingan

Berdasarkan hasil grafik perbandingan ketiga pesawat diatas menjelaskan pesawat yang registrasi PK-WLW dan PK-WLY melakukan maintenance yang sama. Perbandingan grafik pada utilisasi maksimum memerlukan jumlah maintenance yang lebih banyak daripada pesawat PK-WLW dan PKWLY, terutama pada maintenance $50 \mathrm{FH}$ Special Inspection dan $50 \mathrm{FH}$ Servicing. Meskipun utilisasi pada simulasi adalah 8 kali utilisasi kedua pesawat, tetapi jumlah maintenancenya pada umumnya kurang dari 8 kali yang harus dilakukan pada kedua pesawat.

Pada maintenance $\mathrm{CPI}$ jumlah maintenance yang harus dilakukan sama antara ketiga pesawat, artinya pesawat dengan utilisasi rendah tidak efisien dari sisi maintenance menurut calender time. Namun demikian interval maintenance berdasarkan calender time paling rendah adalah 1 tahun atau 12M. Sebagian besar interval tersebut juga menggunakan interval $\mathrm{FH}$ yang cukup rendah, sehingga dengan utilisasi pesawat PK-WLW dan PK-WLY, sebagian maintenance sudah dilaksanakan berdasarkan batas $\mathrm{FH}$ daripada batas calender time. Pada pemeriksaan Supplemental Inspection Directive, jika digunakan simulasi utilisasi maksimum, maka batasan Flight Cycle lebih cepat tercapai daripada batasan calendar, terutama untuk inspeksi dengan interval $500 \mathrm{FC}$.

Pada data utilisasi pesawat PK- WLW dan PK-WLY dapat dikatakan tidak efisien dari sisi maintenance. Sehingga akan lebih menguntungkan kalau utilisasinya banyak dari segi maintenancenya dan operasional pesawat setiap bulannya.Pada kasus utilisasi pesawat PK-WLW dan PK-WLY menurut kelaikan terbang, maka maintenance dalam satu tahun menurut calender time sudah dilaksanakan menurut batasan flight hours. Namun demikian jumlah maintenance yang dilakukan menjadi tidak efisien, terutama dengan adanya prolong sehingga penggunaan pesawat dengan utilisasi rendah tidak efisien dari sisi maintenance. Batasan usia lebih terkait dengan jumlah maintenance yang tidak efisien pada pesawat dengan utilisasi rendah.

\subsection{Operasional}

Berdasarkan aturan maksimum jam terbang dan duty crew pesawat, jika digunakan utilisasi seperti pada pesawat 
PK-WLW dan PK-WLY, maka beban kerja crew tidak pernah terlampaui meskipun hanya menggunakan satu set crew. Hal ini karena utilisasi yang sangat rendah, baik secara Flight Hours maupun secara Flight Cycle. Secara operasional, tidak terdapat perbedaan pengoperasian pesawat berdasarkan umur pesawat. Batasan operasi yang disarankan oleh pabrik pesawat adalah $40000 \mathrm{H}$. Pada kedua pesawat batasan umur tersebut belum tercapai dan masih memiliki banyak sisa umur.

Pesawat PK-WLW memiliki sisa umur 29882.4FH dan pesawat PK-WLY memiliki sisa umur 31405.2FH. Berdasarkan batasan calendar time menurut aturan Perhubungan udara, maka kedua pesawat sudah mencapai batas umur pada tahun 2019, yaitu 45 tahun dari tahun pembuatan 1974. Dengan demikian untuk kedua pesawat tersebut batasan calendar time dengan utilisasi rendah tidak menguntungkan karena sisa umur berdasarkan pabrik masih cukup banyak. Secara operasional tidak ada perbedaan namun secara maintenance tidak efisien untuk utilisasi rendah, meskipun sebenarnya

\section{Kesimpulan}

Berdasarkan analisa data operasional pengaruh usia pesawat cessna 402B terhadap operasional tidak terdapat perbedaan pengoperasian pesawat berdasarkan umur pesawat.

Berdasarkan pengaruh usia pesawat cessna 402B terhadap maintenance menggunakan utilisasi pesawat tidak mempengaruhi jumlah maintenance menurut calender time. Dengan demikian jika pesawat dengan utilisasi rendah dan usia tua maka jumlah maintenance berdasarkan calender time yang harus dilakukan menjadi tidak efisien.

Berdasarkan batas usia kalender pada pesawat cessna 402B dengan frekuensi rendah. Batasan operasi yang disarankan oleh pabrik pesawat adalah $40000 \mathrm{H}$. Pada kedua pesawat batasan umur tersebut belum tercapai dan masih memiliki banyak sisa umur. Pesawat PKWLW memiliki sisa umur 29882.42 FH dan pesawat PK-WLY memiliki sisa umur $31405.2 \mathrm{FH}$.

\section{DAFTAR PUSTAKA}

1. Undang-Undang Nomor 1 Tahun 2009 Tentang Penerbangan.

2. Peraturan Menteri Perhubungan Republik Indonesia Nomor PM 155 Tahun 2016 tentang Batas Usia Pesawat Udara yang digunakan Untuk Kegiatan Angkutan Udara Niaga.

3. 2018, Pengertian Maintenance program https://www.skybrary.aero/index.php/Mai ntenance Programme diakses tanggal 10 Agustus 2019.

4. FAA,. 2008. Aviation Maintenance Technician Handbook, USA.

5. ,. 2018, Pengertian Prolong(FlyableStorage)

Maintenance Program Cessna402 diakses tanggal 19 oktober 2019.

6. Cessna 402 Manufacture's Service Manual Revision 21 dated June 03,2002 ,TRN 11 dated July 2013.

7. FAA., 2009. Fatigue and Performance in Aviation

8. Shannon P. Ackert, 2010, Basics of Aircraft Maintenance Programs for Financiers, USA .

9. Continental Aircraft Engine Operator Manual January 1985 and Overhaul Manual, March 1999.

10. 2018, Aircraft Utilization Report. Berkas Pdf. Febuari 2018. 
